\title{
Study on Improving English Reading Ability of the Electrical Automation Specialty Students in Multimedia-assisted Self-learning
}

\author{
http://dx.doi.org/10.3991/ijet.v11i02.5256 \\ Ruirui Zhang \\ Luoyang Institute of Science and Technology, Luoyang, China
}

\begin{abstract}
For students majoring in Electrical Automation, reading is of vital importance in English learning process. In this paper, the author carries out tests, questionnaires and interviews and finally comes to the conclusion that multimedia-assisted self-learning has an effective impact upon students' English reading ability. It makes students to be the key role of the learning procedure and makes them more active and more independent in English learning and is effective in improving their English reading ability.
\end{abstract}

Index Terms-English teaching; Multimedia-assisted; Selflearning; English reading

\section{INTRODUCTION}

With the development of science and technology, the multimedia-assisted English teaching has become a frequently used teaching method for many college teachers. The students can realize the self-learning by employing the modern multimedia facilities to improve their reading ability freely. Meanwhile, effective ways and strategies should be found to help students to make full use of the multimedia facilities to improve their reading ability. The whole process involves teaching ideas, teaching procedures, learning styles, learning strategies and so on. What's more, the teachers should give some guidance to students to fully involve themselves in selflearning environment and to use various resources effectively within the multimedia facilities. However, in reality, multimedia facilities are often employed in the wrong way, where teachers play the roles using the technology to deliver the learning content to the students. The content is usually an extension of their course notes delivered in PowerPoint slides, from which students will then download into their computer, and ultimately print out to study, or simply video or audio demonstrations that take the place of lectures. As such, the technology itself is the focus of the classroom learning process, and not the content or subject matter.

In fact, it is of great significance for teachers to make use of the modern technologies in their classrooms. There is also a significant move to make curriculum and content more authentic and relevant for student learning (Apple, 2008) and to allow students to become creative thinkers and problem solvers[1]. There is more to utilize information technology than merely upload teaching materials online (Palloff \& Pratt, 2001)[2], and educators still lack the confidence in designing proper learning environments that engage and educate (Chung 2008)[3]. So the research will be of significance on teachers to make use of the modern technologies to help students in English self-learning.

\section{Multimedia-Assisted SELF-LEARNING}

In this section, self-learning, multimedia teaching facilities are reviewed in more details.

\section{A. A brief review of self-learning}

The concept of self-learning stemmed from debates about the development of life-long learning skills and independent thinkers. Ever since the concept was raised, there have appeared a lot of terms, which are equal to or synonymous with the core idea "learner autonomy", such as self-regulated learning, self-instruction, self-directed learning, self-managed learning, self-monitored learning and self-access learning.

Self-learning can be understood as an emerging field of inquiry that encourages reflection on powerful experiences that may influence professional development. Its origins are in a special interest group founded in 1993 entitled The Self-learning of Teacher Education Practices Special Interest Group (Bullough \& Pinnegar, 2001; Hamilton \& Pinnegar, 1998)[4-5]. This special interest group has developed self-learning into an innovative method of inquiry that is highly qualitative in nature, dynamic, interactive and derived mainly from postmodern theory (Bullough \& Pinnegar, 2001; Hamilton \& Pinnegar, 1998; LaBoskey, 2004)[4-6]. The aim of selfstudy is to further understand a deeply personal engagement with a practical experience that leads to and fosters change in knowledge and a way of being in the world (Bullough \& Pinnegar, 2001; LaBoskey, 2004)[4,6]. It is mainly based on self-reflection and it is influenced by a collaborative effort among colleagues and the interrogation of knowledge that occurs amongst them (LaBoskey, 2004)[6].

The application of self-learning may be one of plenty of factors for web-based education to be able to become successful. Self-regulated learning, which refers to an active and constructive process when individuals attempt to adjust their behaviors, supra-cognitive competency and motivation towards learning goals they introduce, limit their goals by guiding with respect to environmental influences, can be said to possess an important function in developing life-long learning skills (Pintrich, 2000; Zimmerman, 2002; Wirth \& Leutner, 2008)[7-9]. Many studies conducted on self-regulated learning put forward that there is a positive significant relationship between students' motivation levels and learning strategies that 
they use and academic accomplishments. These findings led to the concept of self-regulation to be on the rise and politicians, who guides education in distinct countries, and educational psychologists to regard self-regulation as a key to success. The students who use self-regulated learning skills effectively possess three significant qualities. The first one is that they use various cognitive strategies that will assist to configure knowledge and keep it in mind. The second one is that they actively control their own learning by employing supra-cognitive strategies such as planning and observation to control their progress. The last one is that they concentrate on their lessons by self-motivating and solve emotional adversities reasonably (Miltiadou \& Savenye, 2003)[10].

\section{B. Multimedia teaching facilities}

Multimedia teaching facilities mainly include a computer-equipped classroom. All the computers can be connected to the internet. The computers are loaded with Lingdge Teaching Assist System software and other teaching and learning software. Specifically speaking, the multimedia facilities have 3 components:

1) Content and courseware materials that can be downloaded for students' at all time. The courseware is shown in power point software which contains all the learning objects: new words, the passage, grammar and translation, exercises.

2) Lindge Teaching Assist Software which contains teacher control system and database. The teacher can show everything at anytime through the control system. The database contains big amount of learning materials such as reading material, course books, all kinds of tests, video and audio materials etc. The teacher can watch the learning state of the students, show the learning material, ask students to answer questions. Here are some pictures of the control system (Figures 1 and 2).

3) YouDao Online Dictionary which can be used to look up at anytime.

4) Web Browser which can help scan the English Learning Website and search information.

5) QQ Communication Software which helps a QQ group to share the learning information and give feedback to the teacher. The whole procedure is monitored by the teacher and the teacher is on consultation at any time.

\section{Self-learning in multimedia surroundings}

Self-learning in multimedia surroundings is based on the computer technologies which enable the combination of multimedia teaching and self-learning. They also provide significant possibilities and chances for improving the teaching and learning of English reading. One of the most important reasons for adopting multimedia facilities in English reading classes lies in the opportunities they offer for student-centered and interactive procedures. Meanwhile, multimedia learning environments without the restrictions of place, time and physical materials give students free control regarding when, how and what they study (Cunningham \& Billingsley, 2003)[11].

\section{RESEARCH DESIGN}

A research is designed to investigate the application of English self-learning in multimedia surroundings to improve the Electrical Automation Specialty students'

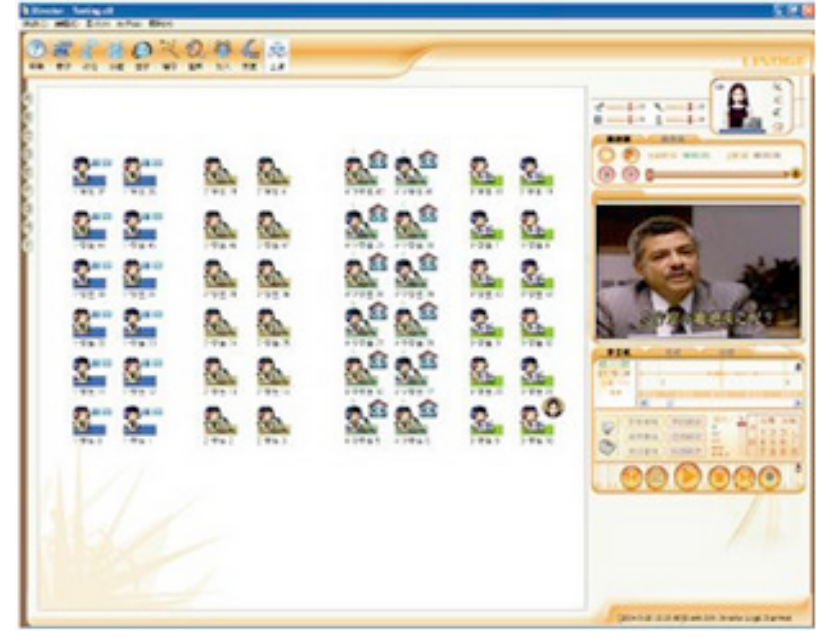

Figure 1. Lindge teaching system

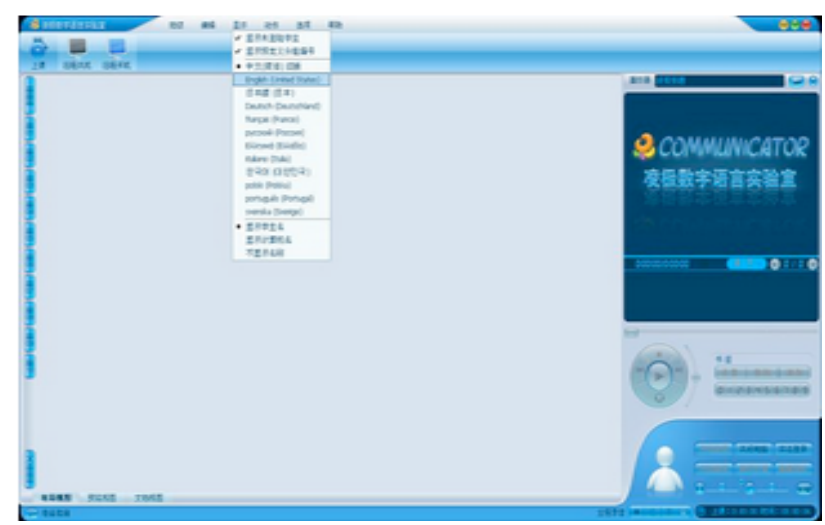

Figure 2. Lindge teaching system

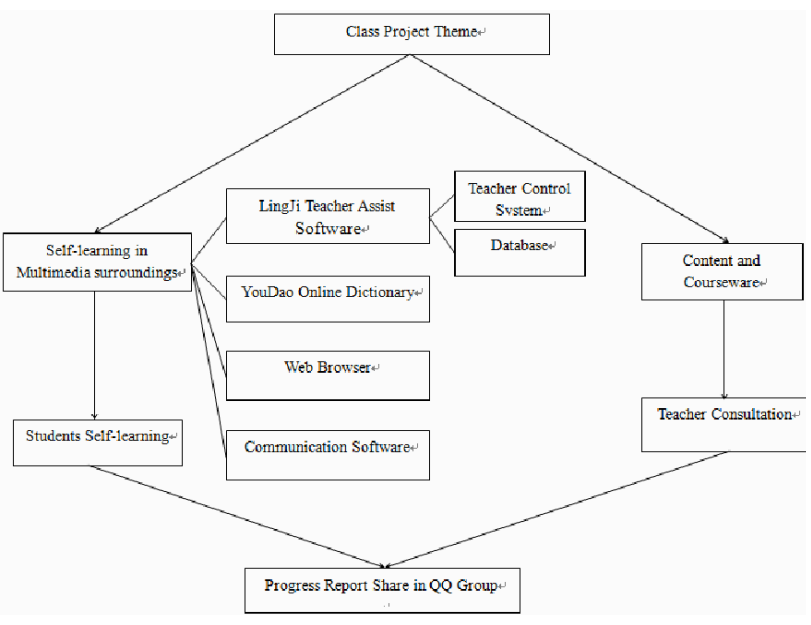

Figure 3. Class project theme

English reading ability. It includes the research questions, research subjects, research procedures, research instruments and teaching procedures.

\section{A. Research questions}

Based on a brief review of the relevant studies, the present one intends to answer the following research questions:

1. What kind of materials and approaches are effective for English reading self-learning? 
2. How to combine the multimedia teaching facilities and the Electrical Automation Specialty students' selflearning?

3. What should both the teachers and students do for English reading self-learning in a multimedia surrounding?

\section{B. Research subjects}

The investigation was carried out in Luoyang Institute of Science and Technology. Class One and Class Two of Grade Two are chosen as the subjects of the study. Both of the two classes consist of 30 students, majoring in Electrical Automation.

\section{Research procedures}

In the chosen two classes, Class One is the experimental group, and Class Two is the controlled. At the beginning of the semester, all the 60 students took a same reading test as the pretest. Then Class One took the experimental teaching for the 16 teaching weeks. Class Two took the traditional teaching approach. They were given another same reading test as the post-test and questionnaire all together at the end of the semester. The author gave some interview to a few students chosen randomly from the two classes. The marks of the tests and the results of the questionnaire and interview were collected and analyzed.

\section{Research instruments}

Test, questionnaire and interview are applied in order to make the study valid and credible.

\section{E. Teaching procedures}

The two groups adopted different teaching procedures. The controlled group took the course in the traditional way: new words learning, background information, question raising, passage translating and explaining, phrases and grammars instruction and doing exercises. The experimental one had these sections with the multimedia facilities assistants and experienced the teaching procedures mainly by themselves under the guidance of the teacher. For the first step, learn the new words and read the passage and relevant materials through PPT courseware. For the second, read the translation and grammar instruction of the passage. For the third, show some English learning web sites to the students and tell them how to search and download and make use of the information from the web sites. Then, let students review the passage and do the exercise in the book. At last, give the students some home work. The students should upload the answers of the exercise and homework to the QQ Group. They can share their learning material, interesting information, feedback and problems of self-learning, suggestion for teachers and so on through the QQ Group.

\section{RESEARCH RESUlTS AND DisCUSSION}

\section{A. Research results of the pretest and post-test}

The pretest was carried out to examine whether the students of the two sampled classes were of similar English reading proficiency before the experiment. The two groups took the same pretest at the same time. The total score of the reading section of the paper is 40 . Table
I shows the average scores of the controlled group and the experimental one.

TABLE I.

AVERAGE SCORES OF TWO GROUPS IN PRETEST

\begin{tabular}{|c|l|c|c|}
\hline \multirow{4}{*}{ Pretest } & Group & $\begin{array}{c}\text { The Number of } \\
\text { Students }\end{array}$ & $\begin{array}{c}\text { The Average } \\
\text { Score }\end{array}$ \\
\cline { 2 - 4 } & Controlled Group & 30 & 30.15 \\
\cline { 2 - 4 } & Experimental Group & 30 & 30.28 \\
\hline
\end{tabular}

Table I shows the average score of the controlled group is 30.15 and the mean score of the experimental group is 30.28 , which are almost the same. There is only a difference of 0.13 between the two groups. The English reading ability level of the controlled group and experimental group is similar, which means that the reading ability of the two groups is much of the same level and they are suitable for the experiment.

TABLE II.

AVERAGE SCORES OF TWO GROUPS IN POST-TEST

\begin{tabular}{|c|l|c|c|}
\hline \multirow{3}{*}{ Post-test } & Group & $\begin{array}{c}\text { The Number of } \\
\text { Students }\end{array}$ & $\begin{array}{c}\text { The Average } \\
\text { Score }\end{array}$ \\
\cline { 2 - 4 } & Controlled Group & 30 & 32.31 \\
\cline { 2 - 4 } & Experimental Group & 30 & 35.29 \\
\hline
\end{tabular}

The average score of the controlled group in the posttest (see Table II) is 32.31 , which is 2.16 and $7.16 \%$ higher than the pretest. The mean score of the experimental group in post-test is 35.29 , which is 5.01 and $16.55 \%$ higher than the pretest. The experimental group really had a great progress for this semester. And the results also show that students of experimental group scored a higher mean of 2.98 than the controlled group after going through the self-learning in multimedia facilities, which makes up $8.4 \%$ of the total score. The average scores of the controlled group and the experimental group are quite different in the post-test. The students of experimental group made much more progress than the students of controlled group. It means the self-learning in a multimedia surrounding is effective to the students' reading ability.

\section{B. Research results of the queationnaires}

In data analysis of questionnaire, the percentage of each answer is analyzed. The first 5 questions of the two questionnaires are the same. The last 5 questions of either questionnaire are quite different.

For question No 1 "Which aspect of the English learning do you like best", most of the students of the two groups chose the reading section. It shows that students like English reading and they are active for the author's study. For question No 2 "What's the purpose of your English learning?" most of the students chose the passing the exams. It shows the press of the English learning. We hope the educational reform will change the status quo. For question No 3 "What's the most difficult for your English reading?" most students chose the new words. It is the information explosion age and the students are not lack of the background information. New words are the big problem of English reading. For question No 4 "Which is the most interesting section of the English reading teaching?" most students chose the background 
information introduction. They can get much knowledge and it is nothing to do with the final exams. When the No 5 question was asked, the students from controlled group chose B (made progress), but the students from experimental group chose A (made big progress). Their feeling is consistent with the final score which is shown in the post-test. The last 5 questions for controlled group are upon the traditional English reading learning mode. For question No 6 "Do you like the teaching mode of the English reading now?" $37 \%$ of the students chose "no feeling", 27\% chose "is OK", 23\% chose "like it very much", $13 \%$ chose "not like it". Most of the students are optimistic about the English reading teaching status quo. They accept and are accustomed to the teaching mode. That's why the traditional teaching mode can survive within the educational reform, but that does not mean it is right or good. The students need a better way of English learning within the electrical facilities and they can made bigger progress. For question No 7 "Do you think the teaching mode is helpful to your English reading?" most students chose "It's helpful" but not "very helpful". For question No 8 "What problem do you have in the traditional teaching method?" $63 \%$ of the students chose "the onefold teaching procedure". $30 \%$ of the students chose "the stereotyped teaching procedure". $7 \%$ of the students chose "the tedious teaching material". So most students don't like the traditional teaching procedure and most of them chose "change the traditional teaching procedure thoroughly" for question No 9. Most students hope to use the multimedia facilities to learn English. The last five questions for experimental group are different with the controlled group. For question No 6 "Do you like the self-learning in multimedia surroundings?" $73 \%$ chose "like it very much"; $17 \%$ chose "it is helpful"; $10 \%$ chose "no feeling" and no one chose "don't like it". But when they are asked "do you think the multimedia teaching should take place of the traditional teaching?" most of them chose "combine them together". It can be seen that the students are deeply impacted by the traditional teaching mode and they don't want to abandon it thoroughly. So the teachers shouldn't change the teaching mode suddenly but let the students get familiar with a new teaching mode step by step. For question No 8 "What kind of help do you hope the teachers to give you?" the difference can be seen from a pie picture.

Teachers should arrange teaching material according to the interest and taste of the students. Although most of the students like the video and audio material, but it doesn't mean they are useful to English learning. The teacher should control the self-learning material and prepare all kinds of useful and related material. The students should follow the guidance and shouldn't indulge in any single form of material.

The last question is "What do you think is the disadvantage and shortcomings of the self-learning in multimedia surroundings?" The pie picture can show the different percentage.

The students don't know what kind of material is useful for learning and they don't know where to get the related material. The teachers should prepare rich learning material and teach students how to get material.

For question No 9 "which section do you think is the most attractive of the self-learning in multimedia surroundings?" the pie picture shows the percentage.
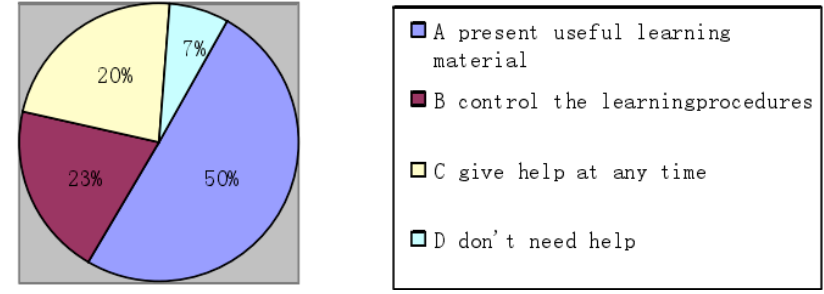

Figure 4. The percentage of answers to question eight
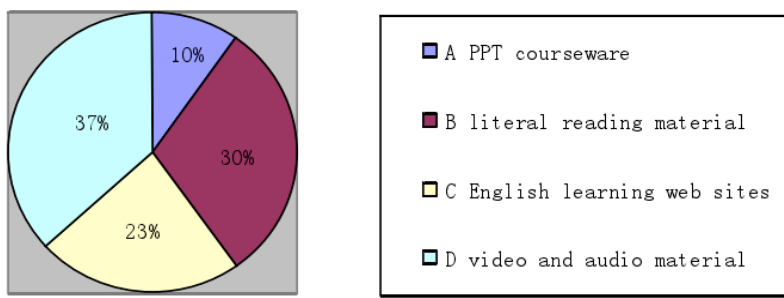

Figure 5. The percentage of answers to question nine
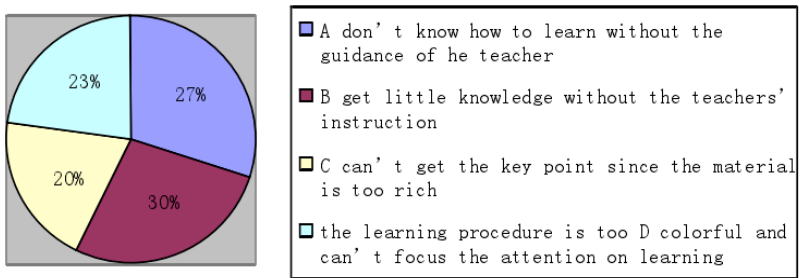

Figure 6. The percentage of answers to question ten

These are the general disadvantages and problems exist in multimedia teaching. So there is not that much difference. The teacher should communicate with the students at any time and get fresh feedback to adjust the learning procedure and reading material and tell the students how to do self-learning effectively and sufficiently.

\section{Research results of the interviews}

The interviews are taken randomly among the students of controlled group and experimental group. Here just list some of the translated answers of the students. To the question "Are you satisfied with the present reading class?" many of the students from controlled group gave a negative answer and considered it boring. To the question "Do you think the present reading class can improve your reading ability?" some students also gave a negative answer. To the question "What are the problems in you reading class?" all the interviewed students listed a lot of problems such as "The class seems so boring. I'm not quite sure what I should do to improve my reading. Sometimes I even don't know for sure our purpose of reading. I hope we can communicative more with the teacher and other classmates". To the question "Do you expect to have English reading class in the website classroom?" all the ten students gave a positive answer. They all expect to have a quite new way of learning English reading. In conclusion, the students were not satisfactory with their present reading class and they want to enjoy the multimedia facilities.

When asked "What is the difference between traditional reading mode and the multimedia mode?" all the interviewed students from experimental group admitted that compared with traditional reading class, the 
atmosphere in multimedia classroom was more relaxing and pleasurable.

The new reading mode receives warmly welcome from students of experimental group. "Reading used to be my weakest part. I felt that English reading was difficult and boring. I didn't want to spend too much time on it, while in multimedia reading class I have a lot to do. The computer and materials make me feel relaxed. This makes the reading process less boring. Sometimes we really create great ideas about certain topics." Some students expressed that the relationship between the teacher and students was different from that in the individual reading classroom. As for this point of view, one student said, "I used to be very afraid of asking questions because it is terrible to face the teacher alone. But now I can communicate with the teacher intimately and the teacher participates in the reading activities together with us. I like this kind of learning." The students also described the different relationship between students. "In traditional reading class, we all focused on our own reading products. But in multimedia reading class, I can communicate and cooperate with my teacher and classmates".

All the students were interested and active with this new mode of learning. As they showed great enthusiasm to learning they would give much effort to reading. Both the teacher and students enjoy this kind of learning and they will make great progress.

\section{Discussion}

From the investigation data discussed above, it is obvious that the experimental group made a great progress. They showed an active and positive adaption to and acceptation with the new learning mode. Besides, the teacher should control the teaching procedure to help the students have a clear direction of reading but not entertainment.

Besides, the incorporation of multimedia and selflearning would further enhance the students' learning process. Technology can become a student's intellectual partner and help them analyze, synthesize and organize their knowledge and comprehension. This is in line with how self-learning activities can be incorporated into online strategies by using multimedia as a technological support, since self-learning activities require learners to apply theoretical knowledge into real context, and incorporating self-learning strategies will have an impact on their cognitive, social and affective behaviors. The multimedia facilities can support multiple representations of the same piece of information in a variety of formats which give learners an authentic learning environment by providing multiple roles and perspectives. With the advent of multimedia facilities and internet technologies, learners are not only passive information receiver but also active information scout. In addition, social networking activities are permeating their learning process and have become extensions of the learner's identity and learning process. This means that students are now processing information, chatting and developing at the same time and no productivity loss is incurred. As such, the learning environments should reflect these new dimensions of learning. The students should know how to choose the learning content, which would motivate students to learn, perform, and achieve better, self-learning materials and meaningful content to provide "just-in-time-delivery", and the integration of technology to become less visible as a separate entity.

Except for that, it has been being argued continuously that with the application of information and communication technologies in education, it brings along different concepts. It indicates that people need more skills to be able to keep up with developing technology and in this case, computer use leads to an inevitable necessity in terms of both individual and social rationales. Computers motivate students effectively, support life-long learning and increase flexibility in education programs. On the other hand, today, learning is regarded as a concept that can emerge not only in schools and specific centers but also in all kinds of environments and every phase of life. Multimedia education presents many opportunities to students such as being able to access course material when and where they can access internet and to communicate with other students. The use of online communication devices in educational environments gained quite significance with the increase of internet use and the usage of computer and internet-supported communication channels became important in interaction. These communication channels can present environments to instructors and students, where both synchronous and asynchronous technologies can be used. The learning environment would blend various learning strategies such as Web-based courseware materials to engage students' cognitive processing skills, a multimedia group project that would require them to collaborate and build management and teamwork skills, and Web Communicating tools to enable them to collaborate and socially network with each other.

\section{CONCLUSION AND OUTLOOK}

The results of the study indicate that the Electrical Automation Specialty students' reading ability in selflearning was successfully enhanced in the multimedia surroundings. The online modules provided important supplemental and richer support for students to increase their understanding of the subject matter, and able to use the valuable information to implement into their projects. They were able to learn how to use multimedia to create multimedia applications and were in line with the using interactive multimedia. In addition, self-learning and deep thinking occurred during the study as students were able to critically process the information needed to solve their project's design problem. By making use of multimedia students found the activities in the module exciting as the students felt the activities were authentic and relevant to their study purpose. This shows that students prefer activities that are relevant to what they are aiming to learn and are based on real world problems as it helps them understand how the theoretical knowledge can be applied in real life situations and solve the practical problems. Therefore the incorporation of self-learning principles played a crucial role in promoting a student's learning process. The communication software and external links provide them the platform and the opportunities to further research the topic and increased their acquired knowledge. Students of the Electrical Automation Specialty were able to demonstrate and support self-learning as they were able to create a final polished product, and not something that was created in preparation of something else. Many of them reported that they now knew what it took to create an interactive multimedia application and developed the 
PAPER

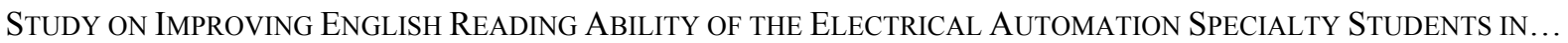

necessary skills to repeat the process when they conduct self-learning after class. Adding integrated authentic assignment was highly beneficial to the students as they mentioned it helped prepare them for their exams and project, and also help them to promoted their reflection on the topics learnt. The authentic activities were effective as students were able to recognize the relevance of the content in the module to their project as they reported that they were able to apply what they learnt from the module into the completion of their project and gain their study results for the beginning aim.

Meanwhile, the use of web searching technologies and social networking tools allowed the whole class to better communicate with each other and give solicit constructive feedback, which are relevant to the effectiveness of their learning process and purpose. By uploading their progress onto the web and commenting on their peers' work, students developed more reflection on their own work and thus paid more attention to the quality of their project, again supporting the reflection strategy. Students had fun in the classroom, in learning from the module as well as in finishing their reading tasks. They were able to claim ownership of their work, be responsible for their learning process and develop a network of collaborators within the classroom setting, which would stand them in good stead for their future careers. In light of this, self-learning has been shown to be effective and efficient in enabling students to learn and become more active and passionate in their learning. Added to that, the incorporation of multimedia, web technologies and students has evolved into becoming "multi-processors" of information. The supplementing traditional in-person methods with webbased activities and resources will make the course more accessible and interactive to cultivate increased student interest and self-exploration for their study.

\section{REFERENCES}

[1] Apple, "Apple Classrooms of Tomorrow-Today Report: Learning in the $21^{\text {st }}$ century", pp. 1-41. Retrieved Jan 22012 from http://ali.apple.com/acot2/global/files/ACOT2_Background.pdf, 2008 .
[2] Palloff, R. M. \& Pratt, K, "Lesson from the cyberspace classroom," The realities of online teaching. San Francisco: JosseyBass Inc, 2001.

[3] Chung, K.C, "Antecedent of Brand Trust in Online Tertiary Education: A Malaysian and Singapore Perspective," International Journal of Business and Management, vol.3, no.4, pp. 3-10, 2008.

[4] Bullough, R., \& Pinnegar, S, "Guidelines for quality in autobiographical forms of self-learning research," Educational Researcher, vol.30, no.3, pp. 13-21, 2001. http://dx.doi.org/10.3102/ 0013189X030003013

[5] Hamilton, M., \& Pinnegar, S, "Conclusion: The value and the promise of self-learning," Reconceptualizing teaching practice: Selfstudy in teacher education (pp. 235-261). Gunpowder Square, London: Routledge Taylor and Francis Group, 1998.

[6] LaBoskey, V, "The methodology of self-learning and its theoretical underpinnings," International handbook of self-learning of teaching and teacher education practices (pp. 817-869). Dordrecht, The Netherlands: Kluwer, 2004. http://dx.doi.org/10.1007/ 978-1-4020-6545-3_21

[7] Pintrich, P.R, "The role of goal orientation in self-regulated learning," Handbook of self-regulation (pp. 451-502). San Diego, CA: Academic Press, 2000. http://dx.doi.org/10.1016/B978-012109 890-2/50043-3

[8] Zimmerman, B. J, "Becoming a self-regulated learner: An overview," Theory into Practice, vol.41, no.2, pp. 64-70, 2002. http://dx.doi.org/10.1207/s15430421tip4102 2

[9] Wirth, J. \& Leutner, D, "Self-regulated learning as a competence. Implications of theoretical models for assessment methods," Journal of Psychology, vol.216, no.2, pp.102-110, 2008.

[10] Miltiadou, M. \& Savenye, W.C, "Applying social cognitive constructs of motivation to enhance student success in online distance education," Educational Technology Review, vol.11, no1, pp. 7895, 2003.

[11] Cunningham, C.A. \& Billingsley, M, Curriculum Webs: A practical guide to weaving the Web into teaching and learning. Boston: Allyn and Bacon, 2003.

\section{AUTHOR}

Ruirui Zhang is a lecturer in School of Foreign Languages, Luoyang Institute of Science and Technology, Luoyang, 471023, China. Her research interests include the applied linguistics, English language teaching, etc. (email: noodles1983@163.com)

Submitted 13 November 2015. Published as resubmitted by the author 28 January 2016. 